\title{
Original Paper \\ Leaf anatomy of Rubiaceae species in a semiarid area of Brazil
}

\author{
Mirella Priscila de Souza Lima ${ }^{1,3}$, Adriana Soares ${ }^{1}$, Jorge Marcelo Padovani Porto ${ }^{1}$, Francisca Souza Sá ${ }^{1}$, \\ Márcia dos Santos Carvalho ${ }^{1} \&$ Francyane Tavares Braga ${ }^{1,2}$
}

\begin{abstract}
Considering the importance of anatomical characters for delimiting Rubiaceae subgroups, the difficulties involved in identifying certain taxa and the lack of studies on that group in the semiarid region, this work aimed to characterize the anatomy of the leaves of 15 species belonging to the genera: Borreria (2), Cordiera (1), Eumachia (1), Hexasepalum (4), Mitracarpus (4), Richardia (1), Staelia (1), and Tocoyena (1) collected in the Serra Branca/Raso da Catarina Environmental Protection Area (Jeremoabo-BA, Brazil), and describe useful elements supporting the group's taxonomy. Variations were found in the shapes and contours of epidermal cells, the presence/absence and types of trichomes, mesophyll type, stomatal type and position, subsidiary cell shapes, vascular system organization, and the occurrence of collector cells and twinned stomata. The results also demonstrated that the anatomical characteristics, when considered together, represent good taxonomic tools for separating the genera and species of Rubiaceae.
\end{abstract}

Key words: caatinga vegetation, morphoanatomy, Raso da Catarina, taxonomy.

\section{Resumo}

Dada a importância dos caracteres anatômicos para delimitação de subgrupos de Rubiaceae, a dificuldade na identificação de determinados táxons, bem como aa escassez de trabalhos sobre o grupo no semiárido, este trabalho objetivou caracterizar a anatomia das folhas de 15 espécies pertencentes aos gêneros Borreria (2), Cordiera (1), Eumachia (1), Hexasepalum (4), Mitracarpus (4), Richardia (1), Staelia (1) e Tocoyena (1) coletados na APA Serra Branca/Raso da Catarina (Jeremoabo-BA, Brasil), e destacar os elementos úteis para subsidiar a taxonomia do grupo. Os resultados mostraram que houve variação quanto ao formato e contorno das células epidérmicas, presença, ausência e tipos de tricomas, tipo de mesofilo, posição e tipo de estômato, formato das células subsidiárias, organização do sistema vascular, ocorrência de células coletoras e estômatos geminados. Foi observado que as características anatômicas, quando utilizadas em conjunto, servem como uma boa ferramenta taxonômica na separação de gêneros e espécies de Rubiaceae.

Palavras-chave: vegetação de caatinga, morfoanatomia, Raso da Catarina, taxonomia.

\section{Introduction}

Rubiaceae is a monophyletic group of easy circumscription (Verdcourt 1958; Bremekamp 1966; Bremer \& Jansen 1991) although there are still problems related to intrafamilial classifications, especially delimitations at the subfamily level (Robbrecht \& Manen 2006), tribe (Bremekamp 1966; Robbrecht 1988; Bremer \& Jansen 1991; Robbrecht \& Manen 2006) and genus (Bacigalupo
\& Cabral 1996). Those problems are related to the requirement for fertile samples to ensure the taxonomic identities of plants collected in the field.

According to Metcalfe \& Chalk (1979), traditional study methods that use herborized plants and their external morphologies as the primary tools for defining the taxa often create persistent taxonomic problems. Although plant anatomy, cytogenetics, and molecular genetics are not as accessible as external morphologies,

\footnotetext{
University of the state of Bahia, Campus VIII, Department of Education, Plant biodiversity graduate program, Street of Gangorra 503, 48608-240, Paulo Afonso,BA, Brazil.

${ }^{2}$ ORCID: < ttps://orcid.org/0000-0002-6088-443X>

${ }^{3}$ Author for correspondence: mirella_priscila@hotmail.com
} 
new tools have been developed in these areas that can define new characters and parameters useful for solving numerous taxonomic problems (Mayr 1998). Anatomical analyses can provide important additional data (in addition to traditional external morphological characteristics) and can be useful for solving taxonomic problems.

Angiosperm leaves demonstrate wide structural variations among different species having high complexity and either simple or highly subdivided structures (Sinha 1999), which can be used to differentiate between individuals from the same population (Mccauley \& Evert 1988).

Although the leaf is the plant organ most exposed to the environment, and therefore the most variable, numerous anatomical characters have systematic value, including the leaf epidermis (Metcalfe \& Chalk 1979; Dickinson 2000), which can be used in phylogenetic studies of the Rubiaceae (Andrade et al. 2015), as taxonomists have continually sought additional anatomical characters that can help identify its species (Solereder 1908; Metcalf \& Chalk 1950, 1979).

The importance of leaf anatomical characters for Rubiaceae was first proposed by Verdcourt (1958) and Bremekamp (1966); Barroso et al. (1978) later separated Rubiaceae subfamilies by their leaf raphides and septate trichomes, with the presence of raphides placing Borreria into Rubioideae (Spermacoceae tribe) and their absence in Chiococca, placing it among the Cinchonoideae (Chiococceae tribe).

Anatomical and micromorphological characters of the leaves of the Rubiaceae with taxonomic significance have been studied in Coussarea (Tavares \& Vieira 1994), Psychotria (Da Cunha \& Vieira 1997; Gomes et al. 1995; Moraes et al. 2011), Bathysa (Nascimento et al. 1996), Rudgea (Mantovani \& Vieira 1997; Leo et al. 1997), Rondeletia (Kocsis et al. 2004), Simira (Moraes et al. 2009), and representatives of the Hamelieae tribe (Martínez-Cabrera et al. 2009).

The present study aimed to characterize the leaf anatomy of 15 species of Rubiaceae species occurring in the Brazilian semiarid region to identify useful characters that could support the group's taxonomy.

\section{Materials and Methods}

\section{Plant material}

Botanical material was collected in the Serra Branca/Raso da Catarina Environmental Protection Area (APASB) $\left(09^{\circ} 53^{\prime} 15.5^{\prime}\right.$ to $09^{\circ} 44^{\prime} 34.6 " \mathrm{~S}$ and $38^{\circ} 49^{\prime} 36,1^{\prime \prime}$ to $\left.38^{\circ} 52^{\prime} 20.4^{\prime \prime} \mathrm{W}\right)$, located in the municipality of Jeremoabo, in northeastern Bahia state, Brazil. The landscape there is flat, with sandstone formations; the regional climate is very hot, the mean annual rainfall near $500 \mathrm{~mm}$, and the mean annual temperature approximately $23{ }^{\circ} \mathrm{C}$ (Szabo et al. 2007).

The adult leaves of three individuals (each), located between the third and fourth node (from the apex to the base) of 15 Rubiaceae species were collected: Borreria spinosa (L.) Cham. \& Schltdl., Borreria verticillata (L.) G. Mey., Cordiera rigida (K. Schum.) Kuntze, Eumachia depauperata (Müll. Arg.) M.R. Barbosa \& M.S. Pereira., Hexasepalum apiculatum (Willd.) Delprete \& J.H. Kirkbr., Hexasepalum gardineri (K.Schum.) J.H. Kirkbr. \& Delprete, Hexasepalum radulum (Willd.) Delprete \& J.H. Kirkbr., Hexasepalum teres (Walter) J.H. Kirkbr., Mitracarpus baturitensis Sucre, Mitracarpus longicalyx E.B. Souza \& M.F. Sales, Mitracarpus robustus E.B. Souza \& E.L. Cabral, Mitracarpus salzmannianus DC., Richardia grandiflora (Cham. \& Schltdl.) Steud., Staelia galioides DC., and Tocoyena formosa (Cham. \& Schltdl.) K. Schum.

Botanical collections were undertaken on different days from May/2014 to June/2015, covering both the rainy and hot/dry seasons, totaling six collections. Samples harvested in the field were herborized following the methodology of Fosberg \& Sachet (1965) and Mori et al. (1989), and subsequently deposited in the herbarium of the state University of Bahia (HUNEB - Paulo Afonso Collection). Fully expanded sun leaves of the third and fourth nodes were selected for study. The fresh materials were fixed in $70 \%$ FAA for 72 hours, according to the methodology described by Johansen (1940). The leaves were then transferred to $70 \%$ ethyl alcohol (v/v) for anatomical procedures.

\section{Light microscopy}

Cross- and paradermic sections of the leaves were prepared following the methodology described by Kraus \& Arduim (1997). The samples were sectioned manually using a razor blade, and stained with astra blue, safranin, and toluidine blue. Semi-permanent slides were prepared using 50\% glycerin (v/v) and photographed using a digital camera (AxioCam ERc5s) coupled to a light microscope (Zeiss Primo Star). The anatomical classifications followed Solereder (1908), Metcalfe \& Chalk (1950), and Appezzato-da-Glória B \& Carmello-Guerreiro SM (2012). 
Similarity analysis

Cluster analysis was performed to evaluate the degrees of similarity among the species studied based on the absence (0) or presence (1) of certain characters, using Euclidean distances and the Average method. Analyses with co-phenotype indices greater than 0.7 were considered significant. Cluster analyses were performed using SYSTAT version 13.0 software (SYSTAT Inc., USA).

\section{Results}

\section{Leaf anatomy}

The leaves of Rubiaceae plants have a thick cuticular layer covering the uniseriate epidermis. The adaxial epidermal surfaces have papillae and anticlinal walls.
The anticlinal adaxial walls appeared straight and polygonal in frontal view in Hexasepalum (except Hexasepalum apiculatum), Richardia (Fig. 1a), and Tocoyena, curved in Cordiera, Borreria verticillata, and Hexasepalum apiculatum (Fig. 1b), and sinuous in Borreria spinosa (Fig. 1c), Mitracarpus, and Staelia. Most species show sinuous and anticlinal abaxial walls. Hexasepalum apiculatum, Hexasepalum radulum, Cordiera, and Tocoyena, however, show curved anticlinal abaxial walls, while those in Hexasepalum teres and Eumachia they are polygonal and straight.

Epidermal cells of different sizes were found on both leaf faces in most species, although they were isodiametric on both faces in Hexasepalum teres and Eumachia; Borreria, Cordiera, Tocoyena, and Mitracarpus baturitensis
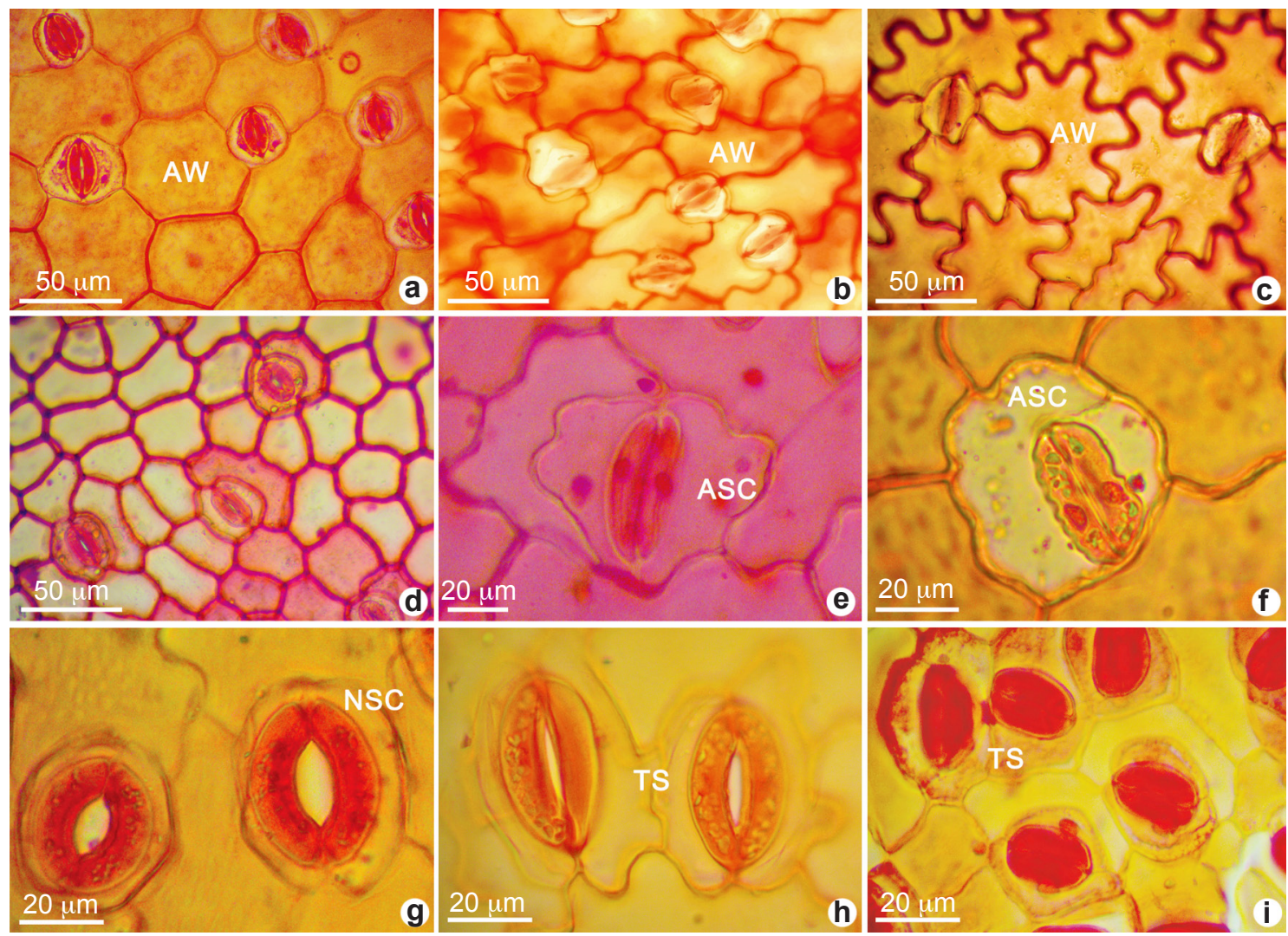

Figure 1 - a. Richardia grandiflora with anticlinal adaxial walls appeared straight and polygonal; $b$. Hexasepalum apiculatum with anticlinal adaxial walls appeared curved; c. Borreria spinosa with anticlinal adaxial walls appeared sinuous; d. Eumachia depauperata with paracytic and anisocytic stomata; e. Mitracarpus robustus with paracytic stomata with abnormal subsidiaries cells; f. Mitracarpus baturitensis showing stomata with abnormal subsidiaries cells; g. Staelia galioides presenting stomata with normal subsidiaries cells; h. Mitracarpus with twinned stomata; i. Tocoyena formos $a$ with grouped twinned stomats. $\mathrm{AW}=$ anticlinal wall, $\mathrm{ASC}=$ abnormal subsidiarires cells, $\mathrm{NSC}=$ normal subsidiarires cells, $\mathrm{TS}=$ twinned stomata. 
demonstrated variations, with isodiametric adaxial cells and different sized abaxial cells.

The leaves of Cordiera, Eumachia, Richardia, Tocoyena, and Hexasepalum radulum are hypostomatic, while the other species presented amphistomatic leaves. Paracytic stomata were observed in all of the species, although Hexasepalum (except Hexasepalum radulum), Eumachia, and Mitracarpus baturitensis also had anisocytic stomata (Fig. 1d).

Malformed subsidiary stomatal cells or abnormal cells were observed in most species (Fig. 1e,f); only Cordiera, Staelia (Fig. 1g), and Hexasepalum teres demonstrated all normal cells. Twinned stomata (Fig. 1h,i) were often seen in Cordiera, Hexasepalum, Mitracarpus (except Mitracarpus robustus), and Tocoyena.

A dorsiventral mesophyll was observed in most species; only Hexasepalum apiculatum and Staelia had isobilateral mesophylls. Collector cells (Fig. 2a) were quite common in the mesophyll, but absent in Eumachia, Richardia, Tocoyena, Mitracarpus baturitensis and Mitracarpus longicalyx.

The numbers of palisade parenchyma layers varied greatly, with Borreria verticillata, Hexasepalum gardineri, Hexasepalum radulum, and Eumachia being unistratified (Fig. 2b), Cordiera and Tocoyena being multistratified (Fig. $2 \mathrm{c})$, while the other species were bistratified.

A vascular midrib system of the collateral type in an open arc (Fig. 2d) was seen in all of the species studied. Tocoyena differed from the others, however, by having a continuous principal vascular bundle in a closed loop (Fig. 1e), with two subjacent accessory bundles; the vascular systems of Cordiera and Eumachia had half-moon outlines (Fig. 1f).

Most species showed angular collenchyma on the abaxial surface of the midrib (Fig. 1g); only Mitracarpus salzmannianus, Richardia, and Staelia did not exhibit that characteristic. Additionally, angular collenchyma were observed on the adaxial faces of Hexasepalum (except Hexasepalum gardineri), Tocoyena, Mitracarpus baturitensis, and Mitracarpus robustus. The taxa Borreria verticillata, Hexasepalum gardineri, Eumachia, and Staelia differed by having collenchyma on the adaxial face of the central cylinder; Cordiera rigida demonstrated both of those characters on the adaxial face.

The vascular bundles of all of those species were composed of sclerenchyma fibers as well as primary phloem and xylem that partially or completely surrounded the main vascular bundles. Cordiera also showed abundant fibers in its secondary bundles.

Tocoyena formosa, which was the only petiolate species in this study, presented a nonfistulous cross section and planar petiole with semi-depressed margins, angular collenchyma with 4-5 cell layers, oval cortical parenchyma cells, and sclerenchyma fibers surrounding the vascular system (which consists of a primary vascular bundle in a closed, continuous arc with accessory strands (Fig. 2h) in the medulla and along the petiole edges), and medulla with irregular cells.

Most species showed various types of raphide-like (Fig. 2i,j) and druse (Fig. 2k) calcium oxaloacetate crystals. Hexasepalum radulum and Tocoyena also contained single crystals (Fig. 21).

Secretory idioblasts were observed in the mesophyll of Mitracarpus longicalyx (Fig. 2m); Hexasepalum radulum and Tocoyena formosa also demonstrated idioblasts in their leaf midribs, and T. formosa in the petiole (Fig. 2n).

Unicellular non-glandular trichomes were observed in all species (except Eumachia depauperata). Multicellular non-glandular trichomes were present in Borreria spinosa, Cordiera, Hexasepalum apiculatum, Hexasepalum radulum, Mitracarpus baturitensis, Mitracarpus robustus, Richardia, and Tocoyena.

Long, non-glandular trichomes were observed in all species, being mostly erect or curved. Hexasepalum gardineri differed by having hook-shaped trichomes, and Tocoyena had abundant and tangled trichomes throughout the leaf. Borreria, Staelia, Mitracarpus baturitensis, and Mitracarpus salzmannianus demonstrated short, thick trichomes, and Hexasepalum teres also bore unicellular glandular trichomes on the blade borders.

\section{Similarity analyses}

Similarity analyses performed based on presence/absence matrices (Tab. 1) distinguished three different groups among the Rubiaceae (Fig. 3a) species studied here. The first group comprised the Psychotrieae tribe (Fig. 3b) (represented by Eumachia depauperata), and the second group the Spermacoceae tribe (Fig. 3c) (represented by Borreria, Hexasepalum, Mitracarpus, Richardia, and Staelia) - both belonging to the Rubioideae subfamily. A third group was formed by the Gardeniae tribe (Fig. 3d) (represented by Cordiera and Tocoyena), belonging to the Ixoroideae subfamily. 

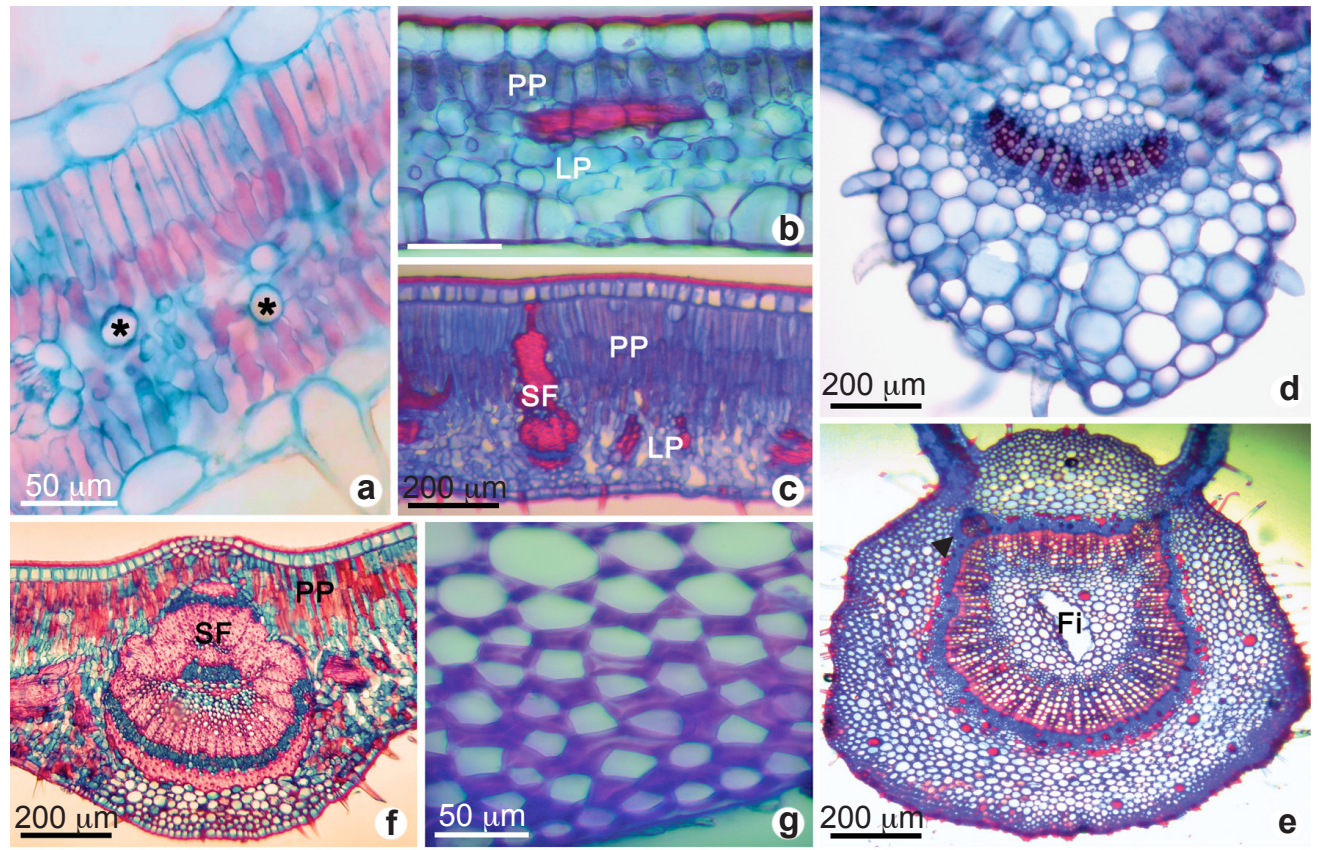

$200 \mu \mathrm{m}$

e
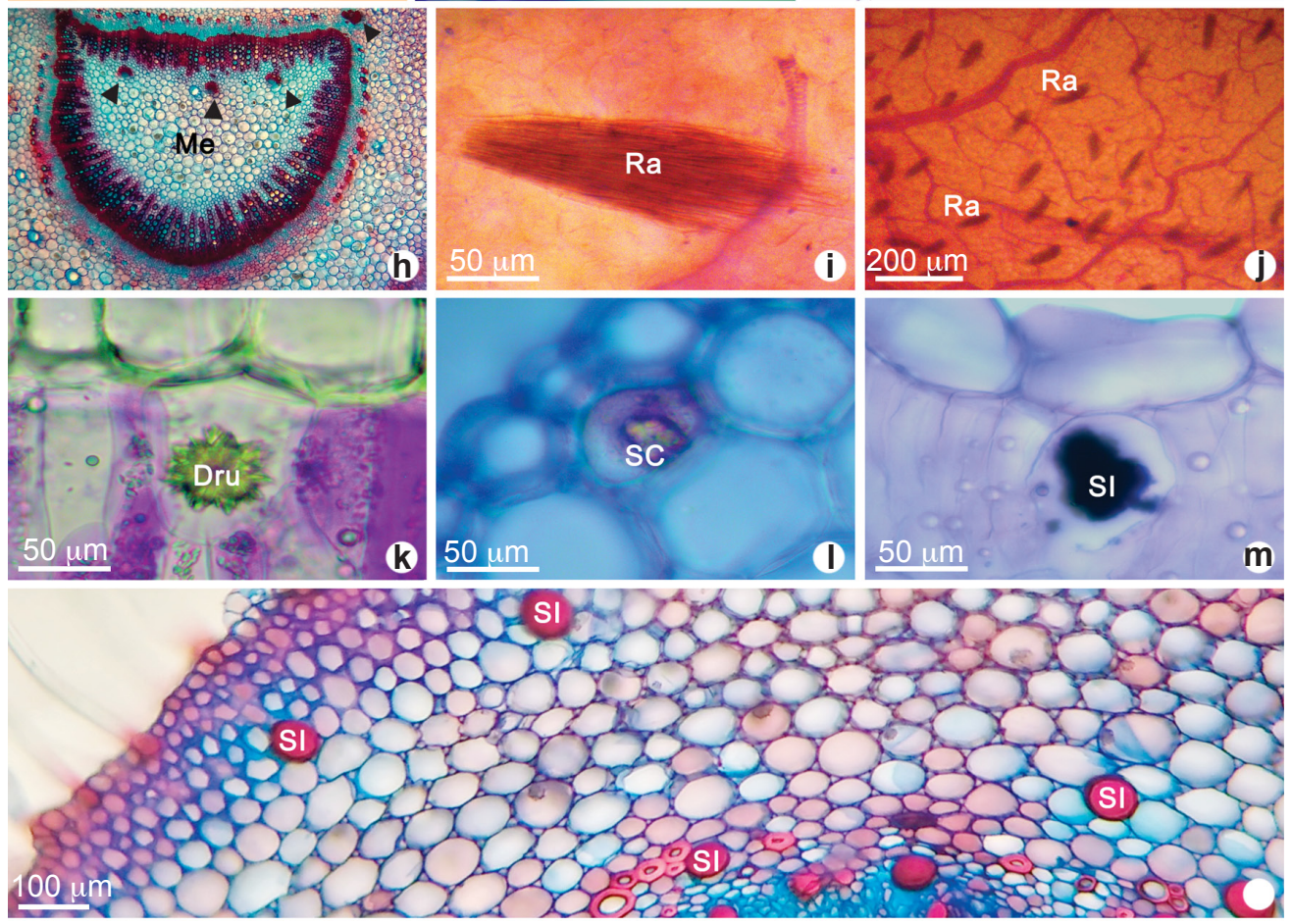

Figure 2 - a. Mesophyll of Hexasepalum apiculatum with biostratified palisadic parenchyma with collector cells; b. Eumachia depauperata with unstratified palisadic parenchyma; c. Cordiera rigida with multistrata palisadeparenchyma and sclerenchyma fibers in the lower bundle; $\mathrm{d}$. Mitracarpus salzmannianus with open arch form vascular system; e. Tocoyena formosa with a continuous principal vascular bundle in closed loop form and subjacent accessory bundles, fistula in the medulla; f. C. rigida with abundant sclerenchyma fiber and vascular system in the form of half moon; $\mathrm{g}$-h. T. formos $a$ with angular collenchyma on the abaxial surface of the midrib and accessory bundles in the petiole; i-k. Hexasepalum teres showing raphides and drusen; 1 . Hexasepalum radulum showing single crystal; $m$. Mitracarpus longicalx with scattered idioblast in the mesophyll; $n$. T. formosa petiole detail with druse and midrib with scattered idioblasts. $\mathrm{PP}=$ palisade parenchyma, $\mathrm{LP}=$ lacunar parenchyma, $\mathrm{SF}=$ sclerenchyma fibers, $\mathrm{Fi}=$ fistula, $\mathrm{SI}=$ secretory idioblasts, ${ }^{*}=$ collector cell $\mathbf{\nabla}=$ accessory bundles, Dru=drusen, Ra=raphides, Me=medulla. 


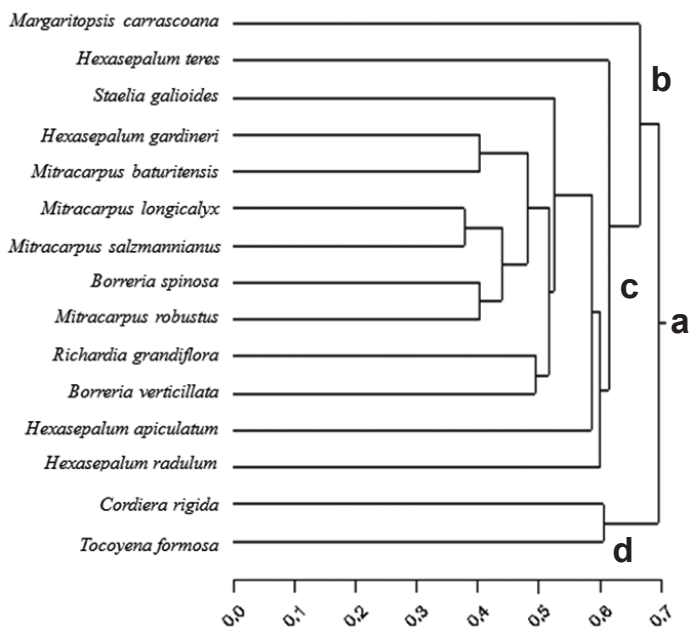

Figure 3 - Similarity analysis - a. Rubiaceae; b. Psychotrieae tribe; c. Spermacoceae tribe; b-c. Rubioideae subfamily; d. Gardenieae tribe, Ixoroideae subfamily.

The characteristics that distinguished Psychotrieae from Spermacoceae were the absence of trichomes, the presence of normal and abnormal subsidiaries cells in the same individual, half-moon shaped vascular bundles, and isodiametric and bulky epidermal cells on both leaf faces.

The most shared characteristics in the Spermacoceae tribe were: amphistomatic leaves, stomata level with the adaxial face, anomalous subsidiary cells, mesophyll with collector cells, arcshaped vascular bundles, angular collenchyma in the midrib, abaxial face, epidermal cells and adaxial papillose, and the absence of druses.

The characters that grouped the Gardenieae tribe were: cell walls with anticlinal curves on their abaxial faces, the absence of papillae on the adaxial epidermis, hypostomatic leaves, only paracytic stomata, multistrata palisade parenchyma, the presence of angular collenchyma in the midrib and adaxial face, and the presence of druses.

\section{Discussion}

The leaf epidermis proved to be useful for the systematics of the Rubiaceae, providing important distinguishing features such as presence of papillae, different epidermal cell sizes, wall shapes and thicknesses, stomatal diversity, and trichome morphologies and distributions (Metcalf \& Chalk 1979; Dickinson 2000; Araújo 2008).

All of the species have leaf blades with uniseriate epidermises, usually with epidermal cells of different sizes on both faces; isodiametric epidermal cells were also commonly found on the adaxial face. Similar results were reported by Mantovani et al. (1995) for Rudgea species. The adaxial faces of the leaves were bulky in most species. Vitarelli (2008) reported the same trait when studying Psychotria carthagenensis. Light and water availability can modulate cell growth and influence cell division processes, epidermal development, and cell volumes (Taiz \& Zeiger 2004; Rizzini 1997; Lambers et al. 1998; Larcher 2000; Zini et al. 2016). The greater volumes of the epidermal cells on the adaxial faces of xeromorphic individuals likely reflects increases in vacuolization to ensure greater water reserves when water restrictions exist due to the high solar irradiation exposure, as in the APASB.

Most of the species studied showed adaxial epidermal papillary cells, with conservative characteristics in Borreria, Hexasepalum, Mitracarpus (except M. robustus), and Staelia that could be used to solve delimitation problems in Spermacoceae, as noted by Mattos (2011) for Borreria. Kay et al. (1981) and Zini et al. (2016) suggested that a papillose epidermis could help reflect sunlight, thus reducing water losses and stabilizing the physiological balances of the plant.

The contours of the leaf epidermal cells corresponded to the patterns described by Metcalfe \& Chalk (1950), with most species demonstrating sinuous cells on the abaxial face, but straight and polygonal cells on the adaxial surface. Isanogle (1944), Combes (1946), Hughes (1959), Gusmão et al. (1992), Dickinson (2000), and Alquini et al. (2012) reported that the sinuous anticlinal walls of epidermal cells are directly related to light effects, and the greater shading the greater the sinuosity. In this study, however, Mitracarpus, Staelia, and B. spinosa demonstrated twisted adaxial epidermal cells even in nonshaded sites; although growing in shaded sites, Hexasepalum teres and Eumachia depauperata had straight, polygonal abaxial epidermal cells. Light, therefore, is not influencing that character in those Rubiaceae species, which enhances its taxonomic usefulness - corroborating Mantovani et al. (1995) and Mattos (2011). According to Medri \& Lleras (1980), the low sinuosity of the cell walls reflects an adaptive strategy against water losses, while Haberlandt (1928) observed that wall sinuosity increased cell stiffness, thus preventing cell collapse under conditions of water stress. 
Table 1 - Matrix of presence (1) and absence (0) of the anatomical characters of 15 species of Rubiaceae from the Serra Branca Environmental Protection Area

\begin{tabular}{|c|c|c|c|c|c|c|c|c|c|c|c|c|c|c|c|}
\hline Characteristics/Species & की & 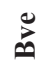 & تָ & 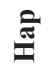 & $\stackrel{\overparen{0}}{\mathbb{x}^{0}}$ & 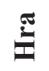 & $\stackrel{\Xi}{ت}$ & $\stackrel{\Xi}{\Sigma}$ & $\stackrel{\text { है }}{\sum}$ & $\stackrel{\rho}{\Sigma}$ & $\stackrel{0}{i}$ & $\sum_{i}^{g}$ & $\underset{0}{\tilde{\sigma}}$ & 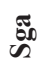 & $\stackrel{\ominus}{H}$ \\
\hline Epidermis: adaxial cells and isodiametric & 1 & 1 & 1 & 0 & 0 & 0 & 1 & 1 & 1 & 0 & 0 & 0 & 0 & 0 & 1 \\
\hline Epidermis: abaxial cells and isodiametric & 0 & 0 & 0 & 0 & 0 & 0 & 1 & 1 & 0 & 0 & 0 & 0 & 0 & 0 & 0 \\
\hline Epidermis: adaxial cells of different size & 0 & 0 & 0 & 1 & 1 & 1 & 0 & 0 & 0 & 1 & 1 & 1 & 1 & 1 & 0 \\
\hline Epidermis: abaxial cells of different size & 1 & 1 & 1 & 1 & 1 & 1 & 0 & 0 & 1 & 1 & 1 & 1 & 1 & 1 & 1 \\
\hline $\begin{array}{l}\text { Epidermis: adaxial cells polygonal, walls straight } \\
\text { and anticlinal }\end{array}$ & 0 & 0 & 0 & 0 & 1 & 1 & 1 & 1 & 0 & 0 & 0 & 0 & 1 & 0 & 1 \\
\hline $\begin{array}{l}\text { Epidermis: abaxial cells polygonal, walls straight } \\
\text { and anticlinal }\end{array}$ & 0 & 0 & 0 & 0 & 0 & 0 & 1 & 1 & 0 & 0 & 0 & 0 & 0 & 0 & 0 \\
\hline Anticlinal wall pattern of adaxial surface curved & 0 & 1 & 1 & 1 & 0 & 0 & 0 & 0 & 0 & 0 & 0 & 0 & 0 & 0 & 0 \\
\hline Anticlinal wall pattern of abaxial surface curved & 0 & 0 & 1 & 1 & 0 & 1 & 0 & 0 & 0 & 0 & 0 & 0 & 0 & 0 & 1 \\
\hline Adaxial surface with sinuous anticlinal walls & 1 & 0 & 0 & 0 & 0 & 0 & 0 & 0 & 1 & 1 & 1 & 1 & 0 & 1 & 0 \\
\hline Abaxial surface with sinuous anticlinal walls & 1 & 1 & 0 & 0 & 1 & 0 & 0 & 0 & 1 & 1 & 1 & 1 & 1 & 1 & 0 \\
\hline Papillose epidermis cells & 1 & 1 & 0 & 0 & 1 & 1 & 1 & 0 & 1 & 1 & 0 & 1 & 0 & 1 & 0 \\
\hline Unicellular trichomes & 1 & 1 & 1 & 1 & 1 & 1 & 1 & 0 & 1 & 1 & 1 & 1 & 1 & 1 & 1 \\
\hline Multicellular trichomes & 1 & 0 & 1 & 1 & 0 & 1 & 0 & 0 & 0 & 1 & 1 & 0 & 0 & 1 & 1 \\
\hline Glandular trichomes & 0 & 0 & 0 & 0 & 0 & 0 & 1 & 0 & 0 & 0 & 0 & 0 & 0 & 0 & 0 \\
\hline Amphistomatic mesophyll & 1 & 1 & 0 & 1 & 1 & 0 & 1 & 0 & 1 & 1 & 1 & 1 & 0 & 1 & 0 \\
\hline Hypostomatic mesophyll & 0 & 0 & 1 & 0 & 0 & 1 & 0 & 1 & 0 & 0 & 0 & 0 & 1 & 0 & 1 \\
\hline Paracytic and anisocytic stomata & 0 & 0 & 0 & 1 & 1 & 0 & 1 & 1 & 1 & 0 & 0 & 0 & 0 & 0 & 0 \\
\hline Stomata leveled with the adaxial face & 1 & 1 & 0 & 1 & 1 & 0 & 1 & 0 & 1 & 1 & 1 & 1 & 1 & 1 & 0 \\
\hline Stomata leveled with the abaxial face & 1 & 0 & 0 & 1 & 0 & 0 & 0 & 1 & 0 & 0 & 1 & 0 & 0 & 0 & 1 \\
\hline Slightly protruding stomata on the abaxial face & 0 & 1 & 0 & 0 & 0 & 1 & 0 & 0 & 0 & 1 & 0 & 0 & 1 & 0 & 0 \\
\hline Protruding stomata on the face abaxial & 0 & 0 & 1 & 0 & 1 & 0 & 1 & 0 & 1 & 0 & 0 & 1 & 0 & 1 & 0 \\
\hline Twinned stomata & 0 & 0 & 1 & 1 & 1 & 1 & 1 & 0 & 1 & 1 & 0 & 1 & 0 & 0 & 1 \\
\hline Subsidiary anomalous cells & 1 & 1 & 0 & 1 & 1 & 1 & 0 & 1 & 1 & 1 & 1 & 1 & 1 & 0 & 1 \\
\hline Dorsiventral mesophyll & 1 & 1 & 1 & 0 & 1 & 1 & 1 & 1 & 1 & 1 & 1 & 1 & 1 & 0 & 1 \\
\hline Isobilateral mesophyll & 0 & 0 & 0 & 1 & 0 & 0 & 0 & 0 & 0 & 0 & 0 & 0 & 0 & 1 & 0 \\
\hline Mesophyll with guard cells & 1 & 1 & 1 & 1 & 1 & 1 & 1 & 0 & 0 & 0 & 1 & 1 & 0 & 1 & 0 \\
\hline Palisade unstratified parenchyma & 0 & 1 & 0 & 0 & 1 & 1 & 0 & 1 & 1 & 0 & 0 & 0 & 0 & 0 & 0 \\
\hline Bistratified Palisade parenchyma & 1 & 0 & 0 & 1 & 0 & 0 & 1 & 0 & 0 & 1 & 1 & 1 & 1 & 1 & 0 \\
\hline Palisade multistrata parenchyma & 0 & 0 & 1 & 0 & 0 & 0 & 0 & 0 & 0 & 0 & 0 & 0 & 0 & 0 & 1 \\
\hline Vascular bundle in the form of open arcs & 1 & 1 & 0 & 1 & 1 & 1 & 1 & 0 & 1 & 1 & 1 & 1 & 1 & 1 & 0 \\
\hline Vascular bundle in the form of half moon & 0 & 0 & 1 & 0 & 0 & 0 & 0 & 1 & 0 & 0 & 0 & 0 & 0 & 0 & 0 \\
\hline Vascular bundle in the form of closed arcs & 0 & 0 & 0 & 0 & 0 & 0 & 0 & 0 & 0 & 0 & 0 & 0 & 0 & 0 & 1 \\
\hline Angular collenchyma in the adaxial midrib & 0 & 0 & 1 & 1 & 0 & 1 & 1 & 0 & 1 & 0 & 1 & 0 & 0 & 0 & 1 \\
\hline Angular collenchyma in the abaxial midrib & 1 & 1 & 1 & 1 & 1 & 1 & 1 & 1 & 1 & 1 & 1 & 0 & 0 & 0 & 1 \\
\hline Palisade parenchyma in the adaxial midrib & 1 & 0 & 1 & 0 & 1 & 0 & 0 & 1 & 0 & 0 & 0 & 0 & 0 & 1 & 0 \\
\hline Raphides type crystals & 0 & 1 & 0 & 1 & 0 & 1 & 1 & 1 & 0 & 1 & 0 & 0 & 0 & 0 & 0 \\
\hline Druses type crystals & 0 & 0 & 1 & 1 & 1 & 1 & 1 & 0 & 0 & 0 & 1 & 0 & 0 & 0 & 1 \\
\hline Single crystals & 0 & 0 & 0 & 0 & 0 & 1 & 0 & 0 & 0 & 0 & 0 & 0 & 0 & 0 & 1 \\
\hline
\end{tabular}

Abbreviations: Bsp- Borreria spinosa; Bve- Borreria verticillata; Cri- Cordiera rigida; Hap- Hexasepalum apiculatum; Hga- Hexasepalum gardineri; Hra- Hexasepalum radulum; Hte- Hexasepalum teres; Mca- Margaritopsis carrascoana; Mba- Mitracarpus baturitensis; Mlo- Mitracarpus longicalyx; MroMitracarpus robustus; Msa- Mitracarpus salzmannianus; Rgr- Richardia grandiflora; Sga- Staelia galioides; Tfo- Tocoyena formosa . 
The amphistomatic stomatal positions observed in the present study differed from the hypostomatic pattern described for most Rubiaceae species by Solereder (1908), Metcalfe \& Chalk (1950), Robbrecht (1988), and Mattos (2011). Only Cordiera, Eumachia, Tocoyena, and Hexasepalum radulum demonstrated hypostomatic leaves. That character therefore demonstrated taxonomic value that could be used in genera circumscriptions, as well as differentiating $H$. radulum from other species in its genus. That stomatal type also differed from the traditional paracytic stomatal pattern associated with Rubiaceae (the 'Rubiaceous type') (Solereder 1908; Accorsi 1947; Metcalf \& Chalk 1950; Bahadur et al. 1971). Here, we identified anisocytic stomata in Hexasepalum (except H. radulum), Eumachia, and Mitracarpus baturitensis in addition to the paracitic stomata type. Those characteristics are essential for differentiating $H$. radulum and $M$. baturitensis from the other species of the genus. Variations of stomatal type in Rubiaceae were also observed by Mantovani et al. (1995), Da Cunha \& Vieira (1997), Vitarelli (2008), and Mattos (2011), who all reported paralelocytic stomata.

Accorsi (1947) and Pant \& Mehra (1965) observed that the stomatal subsidiaries cells in Rubiaceae species showed anomalous morphological defects due to incomplete and uneven development. Although the ontogeny of those peculiar stomata in the species studied here was not examined, they were considered anomalous because of their similarities to those described by the aforementioned authors.

Some species demonstrated grouped stomata (described as twinned stomata by Accorsi [1947]) or malformed subsidiary cells; those finding agree with the studies of Mantovani et al. (1995) and Gavilanes et al. 2016. Accorsi (1947) reported the presence of twinned stomata in $39.45 \%$ of a total of 601 Rubiaceae species. Most of the species studied here showed anomalous stomatal cells, and only the genera Cordiera and Staelia, and $H$. teres genera showed normal cells. The genus Eumachia demonstrated both normal and abnormal stomata cells; twinned stomata were recorded in the genera Cordiera, Hexasepalum, Mitracarpus (except M. robustus), and Tocoyena.

The most common type of vascular midrib seen here was in the form of an arc, corroborating the studies of Holm (1907), Solereder (1908), and Metcalfe \& Chalk (1950); a half-moon type variation was seen in the genera Cordiera and Eumachia. The genus Tocoyena could be distinguished by the arrangement of its vascular system, with a continuous main bundle in a closed arc, with two subjacent accessory bundles on the adaxial face; Coelho et al. (2006) reported that same morphology.

Sclerenchyma fibers were associated with the phloem in most species, completely or partially surrounding the vascular bundles. Sclerenchyma fibers were abundant in the principal and secondary veins in the genus Cordiera genus, but those fibers were scarce and ungrouped in Tocoyena and collateral (except in $T$. formosa), and were usually surrounded by an endoderm layer; a vascular sheath was seen in the species $B$. verticillata, $H$. apiculatum, and $H$. teres, as well as in Richardia and Staelia. The abundances of those fibers are related to greater tissue stability in xerophytic plants, and they help avoid cell collapse during dry periods as well as mechanical stress due to strong winds (Esau 1977; Krahl et al. 2013; Krahl \& Krahl 2017).

A dorsiventral mesophyll was observed in the majority of the species studied here, corroborating with the family descriptions of Solereder (1908) and Metcalfe \& Chalk (1950). Hexasepalum apiculatum and Staelia galioides, however, showed an isobilateral mesophyll, which is an important character for their differentiation. Collector cells were observed in Cordiera, Borreria, Hexasepalum, Staelia, Mitracarpus baturitensis, and M. longicalyx. Collector cells are formed by the connection of spongy parenchyma cells to palisade parenchyma cells (thus differing from other foam cells). Those cells consistently occur in Rubiaceae species, and have taxonomical value (Lersten 1974; Scatena \& Scremin-Dias 2012).

According to Mattos (2011) and Teixeira et al. (2016), trichomes have taxonomic value in the Rubiaceae. Their importance may vary according to the hierarchical level analyzed, with Kocsis et al. (2004) demonstrating that trichome types, especially abaxial leaf trichomes, can be used to distinguish Rodeletia species. Martínez-Cabrera et al. (2009) observed that the types, sizes, and distributions of trichomes are important characteristics for separating genera in the Hamelieae tribe. Trichomes have an indirect influence on water conservation in plants by reflecting back solar radiation that strikes the leaves (Salatino et al. 1986; Larcher 2000) and, at high densities, they are responsible for 
maintaining a saturated water vapor atmosphere (Fahn \& Cutler 1990; Larcher 2000). Trichomes were found here to be important in distinguishing species such as Hexasepalum apiculatum, which has dense, elongated multicellular trichomes, but $H$. teres does not; $H$. teres, on the other hand, has glandular marginal trichomes but $H$. apiculatum does not. The presence of glandular trichomes in $H$. teres was also reported by Mussury et al. (2012). Those species are commonly confused in taxonomic studies, resulting in misidentifications. The anatomical characters observed here point to identifiable differences between the species.

Hexasepalum apiculatum is described here for the first time or the APASB.

Similarity analyses showed that the presence of papillae on the adaxial epidermis, the presence or absence of trichomes, stomatal type, variations of palisade layer morphologies, stomatal classification and position, subsidiary cell shape changes during vascular system formation, epidermal cell sizes, the morphologies of the anticlinal walls, the presence of collector cells, the types of crystals, and the angular dispositions of the midrib collenchyma are useful characteristics for the taxonomy of Rubiaceae species. According to Vasconcelos et al. (2017), crystal types represent important diagnostic features for the genera and species of Rubiaceae.

Some of these characteristics have been used in anatomical studies applied to the taxonomy of the Rubiaceae (Tavares \&Vieira 1994; Nascimento et al. 1996; Kocsis et al. 2004; Moraes et al. 2009; MartínezCabrera et al. 2009; Moraes et al. 2011; Mattos 2011), so that the results reported here can contribute to a better understanding of the phylogenetic relationships among the taxa of that family.

The similarity analyses corroborated the current circumscription of Rubiaceae proposed by Bremer \& Eriksson (2009).

These results confirm the importance of leaf anatomical characters as additional tools that can support taxonomic studies in Rubiaceae and increase our anatomical, ecological, and physiological knowledge of the subfamily, tribe, genera, and species, and indicate promising characters for future taxonomic and phylogenetic approaches.

\section{References}

Accorsi WR (1947) Ocorrência das células anexas dos estômatos na família Rubiaceae. Anais da Escola Superior de Agricultura "Luiz de Queiroz" 4: 421-436.
Alquini Y, Bona C, Costa CG \& Barros CF (2012) Epiderme. In: Appezato-da-Glória B \& CarmeloGuerreiro SM (eds.) Anatomia vegetal. $3^{\mathrm{a}}$ ed. Editora UFV, Viçosa. 85p.

Andrade ER, Jardim JG, Santos BA, Melo FPL, Talora DC, Faria D \& Cazetta E (2015) Effects of habitat loss on taxonomic and phylogenetic diversity of understory Rubiaceae in Atlantic forest landscapes. Forest Ecology and Management 349: 73-84.

Appezzato-da-Glória B \& Carmello-Guerreiro SM (2012) Anatomia Vegetal. $3^{\mathrm{a}}$ ed. Editora UFV, Viçosa. 404p.

Araújo JS (2008) Anatomia foliar de 16 espécies de Malpiguiaceae ocorrentes em área de cerrado (MG). Dissertação de Mestrado. Universidade Federal de Viçosa. Viçosa. 39p.

Bacigalupo NM \& Cabral EL (1996) Infrageneric classification of Borreria (Rubiaceae-Spermacoceae) on the basis of American species. Opera Botanica Belgica 7: 297-308.

Bahadur B, Rajagopal T \& Ramayya N (1971) Studies on the structural and developmental variation and distribuction of stomata in the Rubiaceae. The Botanical Journal of the Linnean Society 64: 295-310.

Barroso GM, Guimarães EF, Ichaso CLF, Costa CG \& Peixoto AL (1978) Sistemática de angiospermas do Brasil. LTC, Rio de Janeiro. 255p.

Bremekamp CEB (1966) Remarks on the position, the delimitation and the subdivision of the Rubiaceae. Acta Botânica Nearlandica 15: 1-33.

Bremer B \& Jansen RK (1991) Comparative restriction site mapping of chloroplast DNA implies new phylogenetic relationships within Rubiaceae. American Journal of Botany 78: 198-213.

Bremer B \& Erikisson T (2009) Time tree of Rubiaceae: phylogeny and dating the family, subfamilies, and tribes. International Journal of Plants Sciences 170: 766-793.

Coelho VPM, Agra MF \& Barbosa MRV (2006) Estudo farmacobotânico das folhas de Tocoyena formosa (Cham. \& Schltdl.) K. Schum. (Rubiaceae). Revista Brasileira de Farmacognosia 16: 170-177,

Combes R (1946) Latimne des végétoux el le milieu. Librarie Annand Colin, Paris. 222p.

Da Cunha M \& Vieira RC (1997) Anatomia foliar de Psychotria velloziana Benth. (Rubiaceae). Rodriguésia 45: 39-50.

Dickinson WC (2000) Integrative plant anatomy. Harcourt Academic Press, San Diego. 533p.

Esau K (1977) Anatomy of seed plants. 2a ed. John Wiley \& Sons, New York. 576p.

Fahn A \& Cutler D (1990) Xerophytes. Bruder Bomtraeger, Berlin. 176p.

Fosberg FR \& Sachet MH (1965) Manual for tropical herbaria. Regnum Vegetabile. Vol 39. Internacional Bureal for Plant Taxonomy and Nomenclature. Utrecht, Netherlands. 132p. 
Gavilanes ML, Castro EM, Pires MF, Pereira FJ \& Pereira MP (2016) Micromorfometria foliar de palicourea rigida kunth. (rubiaceae) em ambiente de cerrado e campo rupestre. CERNE 22: 163-170.

Gomes DMS, Mantovani A \&Vieira RC (1995) Anatomia foliar de Psychotria ternuinerves Müll. Arg. e Psychotria sternocalix Müll. Arg. (Rubiaceae). Arquivos de Biologia e Tecnologia 38: 15-33.

Gusmão ED, Souza JP, Silva IMS \& Silva LB (1992) Estudo anátomo-morfológico de dicotiledôneas das dunas de Salvador-Bahia. Borreria cymosa Cham. Et Schul. e Chiococca bracheata R. et. P. (Rubiaceae). Acta Botânica Brasílica 6: 79-98.

Haberlandt G (1928) Physiological plant anatomy. $4^{\mathrm{a}}$ ed. Macmillan, London. 324p

Holm T (1907) Rubiaceae: anatomical studies of North American representatives of Cephalanthus, Oldenlandia, Houstonia, Mitchella, Diodia and Galium. Botanical Gazette 43: 153-189.

Hughes AP (1959) Effects of the environment of leaf development in Impatiens parviflora DC. The Journal of the Linnean Society Botany 56: 161-165.

Isanogle IT (1944) Effect of controlled shading upon the development of leaf structure in two deciduous tree species. Ecology 25: 409-413.

Johansen DA (1940) Plant microtechnique. Mc GrawHill, New York. 523p.

Kay QON, Daoud HS \& Stirton CH (1981) Pigment distribution, light reflection and cell structure in petals. Botanical Journal of the Linnean Society 83: 57-84.

Kocsis M, Darók J \& Borhidi A (2004) Comparative leaf anatomy and morphology of some neotropical Rondeletia (Rubiaceae) species. Plant Systematics and Evolution 248: 205-218.

Krahl AH \& Krahl DRP (2017) Anatomia foliar de Orleanesia yauaperyensis Barbosa Rodrigues (Orchidaceae). Biota Amazônica 7:63-65.

Krahl AH, Holanda SS, Krahl DRP, Correa MM, Oliveira RLC \& Valsko JJ (2013) Anatomia foliar de Ananas lucidus Mill. (Bromeliaceae). Natureza Online 11: 161-165.

Kraus JE \& Arduin M (1997) Manual básico de métodos em morfologia vegetal. EDUR, Rio de Janeiro. 198p.

Lambers H, Stuart F \& Pons TL (1998) Plant physiological ecology. Springer-Verlag, New York. 540p.

Larcher W (2000) Ecofisiologia vegetal. Rima, São Carlos. 531p.

Leo RRT, Mantovani A \& Vieira RC (1997) Anatomia foliar de Rudgea ovalis Müll. Arg. e R. tinguana Müll. Arg. (Rubiaceae). Leandra 12: 33-44.

Lersten NR (1974) Morphology and distribution of colleters and crystals in relation to the toxonomy and bactelialleaf nodule symbiosis af Psychotria (Rubiaceae). American Journal of Botany 61: 973-981.
Mantovani A \& Vieira RC (1997) Leaf surface of two understoreyshrubs Rudgea decipiens Müll. Arg. And Rudgea macrophylla Benth. (Rubiaceae). Rodriguésia 49: 7-13.

Mantovani A, Gomes M, Gomes DMS \& Vieira RC (1995) Anatomia foliar de Rudgea decipiens Müll. Arg. and R. macrophylla Benth. (Rubiaceae). Acta Botanica Brasílica 9: 247-261.

Martínez-Cabrera D, Terrazas T \& Ochotorena H (2009) Foliar and petiole anatomy of tribe Hamelieae and other Rubiaceae. Annals of the Missouri Botanical Garden 96: 133-145.

Mattos KLBL (2011) Anatomia foliar aplicada à taxonomia em Rubiaceae Juss. Tese de Doutorado. Universidade Federal de Viçosa, Viçosa. 90p.

Mayr E (1998) O desenvolvimento do pensamento biológico: diversidade, evolução e herança. Editora Universidade de Brasília, Brasília. 1107p.

Mccauley MM \& Evert RF (1988) Morphology and vasculature of leaf of potato (Solanum tuberosum). American Journal of Botany 75: 377-390.

Medri, ME \& Lleras E (1980) Aspectos da anatomia ecológica de folhas de Hevea brasiliensis Mucll. Arg. Acta Amazonica 10: 463-493.

Metcalfe CR \& Chalk L (1950) Anatomy of the dicotyledons: leaves, stem, and wood in relation to taxonomy with notes on economic uses. Clarendon Press, Oxford. 724p.

Metcalfe CR \& Chalk L (1979) Anatomy of the dicotyledons: systematic anatomy of leaf and stem with a brief history of the subject. Clarendon Press, Oxford. 453p.

Moraes TMS, Barros CF, Neto SJS, Gomes VM \& Da Cunha M (2009) Leaf blade and ultrastructure of six Simira species (Rubiaceae) from the Atlantic Rain Forest, Brazil. Biocell 33: 155-165.

Moraes TMS, Rabelo GR, Alexandrino CR, Silva Neto SJ \& Da Cunha M (2011) Comparative leaf anatomy and micromorphology of Psychotria species (Rubiaceae) from the Atlantic Rainforest. Acta Botanica Brasilica 25: 168-177.

Mori SA, Silva LAM, Lisboa GE \& Coradin L (1989) Manual de manejo do Herbário Fanerogâmico. Centro de Pesquisa do Cacau, Ilhéus. 104p.

Mussury RM, Pereira ZV \& Scalon SPQ (2012) Comparison of leaf morphoanatomy of Diodella radula (Willd. \& Hoffmanns. ex. Roem. \& Schult.) Delprete and Diodella teres (Walter) Small (Rubiaceae). International Journal of Plant Research 2: 41-45.

Nascimento MVO, Gomes DMS \& Vieira RC (1996) Anatomia foliar de Bathysa stipulata (Vell.) Presl. (Rubiaceae). Rev Unimar 18: 387-401.

Pant DD \& Mehra B (1965) Ontogeny of stomata in some Rubiaceae. Phytomorphology 5: 300-310. 
Rizzini CT (1997) Tratado de fitogeografia do Brasil: aspectos ecológicos, sociológicos e florísticos. Âmbito Cultural Edições, Rio de Janeiro. 747p.

Robbrecht E (1988) Tropical woody Rubiaceae. Characteristic features and progressions. Contributions to a new subfamilial classification. Opera Botanica Belgica 1: 1-271.

Robbrecht E \& Manen CF (2006) The major evolutionary lineages of the coffee family (Rubiaceae, angiosperms). Systematics Geography Plants 76: 85-146.

Salatino A, Montenegro G \& Salatino MLF (1986) Microscopia eletrônica de varredura de superfícies foliares de espécies lenhosas do cerrado. Revista Brasileira de Botânica 9: 117-124.

Scatena VL \& Scremim-Dias E (2012) Parênquima, colênquima e esclerênquima. In: Appezato-daGlória B \& Carmelo-Guerreiro SM (eds.) Anatomia vegetal. $3^{\mathrm{a}}$ ed. Editora UFV, Viçosa. 105p.

Sinha N (1999) Leaf development in angiosperms. Annual review of plant physiology and plant molecular biology 50: 419-446.

Solereder H (1908) Systematic anatomy of the dicotyledons. Clarendon Press, Oxford. 1182p.

Szabo AV, Rocha ACS, Tosato JAC \& Barroso W (2007) Área de Proteção Ambiental (APA) Serra BrancaRaso da Catarina. In: Marques J (org.) As Caatingas: debates sobre a Ecorregião do Raso da Catarina. Fonte Viva, Paulo Afonso. 39p.

Taiz L \& Zeiger E (2004) Fisiologia vegetal. Artmed, Porto Alegre. 449p.

Tavares ES \& Vieira RC (1994) Anatomia foliar de Coussarea meridionalis (Vell.) Muel. Arg. e Coussarea graciliflora Benth. \& Hook (Rubiaceae). Boletim do Herbário Bradeanium 39: 320-330.

Teixeira TR, Pádua MS \& Castro AHF (2016) Leaf anatomy of Cordiera Sessilis (Vell.) Kuntze (Rubiaceae). Acta Scientiarum 38: 355-364.

Vasconelos AL, Santos AV, Padilha RJR, Alves LC \& Randau KP (2017) Anatomical characterization of ultra-structures, biominerals and histolocalization of metabolites in leaves of Genipa americana. Revista Brasileira de Farmacognosia 27: 541-548.

Verdcourt B (1958) Remark on the classification of the Rubiaceae. Bulletin du Jardin botanique de l'état à Bruxelles 28: 209-281.

Vitarelli NC (2008) Morfoanatomia foliar da reófita facultativa Psychottria cartagenensis Jacq. (Rubiaceae). Dissertação de Mestrado. Universidade Federal de Santa Catarina, Florianópolis. 76p.

Zini AS, Martins S, Toderke ML \& Temponi LG (2016) Anatomia foliar de Rubiaceae ocorrentes em fragmento florestal urbano de Mata Atlântica, PR, Brasil. Hoehnea 43: 173-182. 